\title{
Post-Conflict Experiences of Resettled Bakassi Peninsula People, 2006-2016
}

\author{
Aloysius Nyuymengka Ngalim
}

\begin{abstract}
The Greentree Agreement of 2006 between Cameroon and Nigeria ended the conflict over the ownership of the oil and fish rich Bakassi Peninsula in favor of Cameroon and created problems for the relocated and resettled Nigerians. This article argues that contrary to the generally accepted theory by many scholars that heritage values are often the concern of displaced persons, we found that practical economic needs and the desire for functional participation in governance of those relocated in New Bakassi have been the main problems of the displacees leading to an indigenousincomer divide that could generate a crisis that may degenerate into intractable conflict. The study reveals that due to government insensitivity and corruption, proper resettlement for Bakassi returnees is yet to be addressed.
\end{abstract}

Keywords conflict, Bakassi, Cameroon, Nigeria, economic needs, proper resettlement

\section{Introduction}

Boundary adjustments are not common features of African state territoriality. The colonially-ordered boundaries, despite their problems, were adopted and reified by postcolonial African leadership as the basis for territoriality and ordering postcolonial interstate relations. Indeed, the recent World Courtordered boundary adjustment (or settlement) between Nigeria and Cameroon is the exception rather than the rule. The exercise relocated settlements, moving some from Nigeria to Cameroon and vice versa, along the length of their shared $1,600 \mathrm{~km}$ boundary. The purpose of this article is to investigate the post-conflict experiences of persons affected by the displacement, relocation, and resettlement of the vast majority of the approximately 300,000 inhabitants of the Bakassi Peninsula into New Bakassi in Cross River State, Nigeria. The study explores the factors that influenced the choice of the displaced inhabitants of Bakassi to relocate, the implications of resettlement or new identities on the affected people 
of Bakassi, and how they are being effectively integrated into their communities. The initiatives to promote the socio-economic as well as the cultural interests of the affected people are analyzed and, finally, the implications of integration and resettlement on sustainable peace and development are examined.

\section{Background}

The Bakassi Peninsula was the subject of a protracted dispute and an armed conflict between Nigeria and Cameroon over the exercise of sovereignty and ownership. Nigeria and Cameroon engaged in hostilities in 1972-1973 and after many years of low-keyed sporadic attacks by both sides; the first major use of direct violence took the form of a military conflict on May 16, 1981 (Konings 2005, 290; Price 2005). In 1981, Cameroon and Nigeria were at the brink of war over the Bakassi Peninsula and some islands in Lake Chad. Hostilities continued intermittently through the 1980s and reached a tipping point in the early 1990s when more armed clashes were recorded between these countries over ownership of the Peninsula. In 1993, armed conflict in the area led to the loss of casualties (Ekolok n.d., 40; Konings 2005, 292). Cameroon headed to the International Court of Justice (ICJ) in 1994 to seek a resolution of the protracted issue. The ICJ decision, after years of claims and counterclaims, mandated Nigeria to transfer Bakassi Cameroon. Nigeria initially rejected the ruling, but later agreed to the terms of the Greentree Agreement, midwived by United Nations (UN) SecretaryGeneral Kofi Annan, to ensure peaceful compliance with the ruling of the ICJ.

According to the Agreement, Nigeria committed itself to recognize "the sovereignty of Cameroon over the Bakassi Peninsula in accordance with the judgment" and to "withdraw all its armed forces from the Bakassi Peninsula within sixty days of the date of the signing of this Agreement." The UN SecretaryGeneral could extend that period but not for more than a total of thirty days. Cameroon, after the transfer of authority to it by Nigeria, "guarantees to Nigerian nationals living in the Bakassi Peninsula the exercise of the fundamental rights and freedoms enshrined in international human rights law and in other relevant provisions of international law." Cameroon was not to expel Nigerian nationals from the area or force them to change their nationality. They were to be left to enjoy the rights to their "culture, language and beliefs...their agricultural and fishing activities...p property and...customary land rights" among other rights (IC) 2002).

Notwithstanding the sustained opposition within Nigeria, Nigeria began the transfer of the Peninsula to Cameroon in August 2006 when Nigerian troops were pulled out of the northern part of the disputed territory. The process was concluded in 2008 when Nigeria handed over the entire Peninsula to Cameroonian authorities. There was strong resistance from the Bakassi 
Movement for Self-Determination and Independence. They objected to relocation to other parts of Nigeria. Some of the Bakassians rejected the decision of the ICJ on the grounds that they were not consulted in the determination of their destiny and the neglect of the overwhelming desire of the affected people to remain Nigerian citizens. According to Honourable Essien Ayi, the representative of the Bakassi/Calabar South/Akpabuyo Federal Constituency at the National Assembly, "the GTA [Greentree Agreement] presented the Bakassi people with three hard choices: to remain in Bakassi and become Cameroonians; as Nigerians but live like immigrants and retain their Nigerian citizenship and; leave their ancestral homes to become eternal refugees in Nigeria" (Iriekpen and Nzeshi 2012).

In spite of the handover, the Bakassi issue was not closed until the ten year window for appeals allowed by the ICJ closed on October 10, 2012. Within Nigeria, there were heightened agitations for an appeal as the prospect of the perpetual loss of the Peninsula became inevitable. Civil society groups, opposition political parties, and some prominent Bakassi indigenes, amongst other interested parties, led the agitation to reclaim the Peninsula. The Nigerian National Assembly, particularly the Senate, was at the forefront of the movement to prevent the loss of the Peninsula. It passed a resolution on the eve of the appeal deadline urging the Nigerian government to invoke Article 61 of the ICJ Statute to appeal the decision in the interest of Nigerians in the affected area. However, the Nigerian government, during the administration of President Olusegun Obasanjo, refused to appeal the decision, having considered all the options before it. Hence, on October 10, 2012, Bakassi became an inalienable part of the Republic of Cameroon (Dos Santos 2014, 1-2).

There have been several contentions that one of the bases for the failure of the state in Africa is the tendency for policymakers to overlook the critical historical, cultural, and social context of society. The neglect of the historical, social, and cultural context of the affected people of Bakassi in the process of their displacement, relocation, and resettlement could create more problems than solutions, especially for the bulk of the population that relocated to Nigeria. As the friction between original residents of Akpabuyo and the resettled people over access to resources deepens, conflict and violence may ensue. Indeed, findings revealed that the affected people are already experiencing some form of deprivation or the other in their new home. They have no access to fishing, their main occupation, as their new homes are located far from the sea; they are deprived of access to relief materials; and they are marginalized and oppressed. The affected people thus may gradually become disillusioned, disaffected, and tend to aggression, owing to their social and economic deprivation. On the other side in Bakassi, Cameroon, the Nigerians citizens, who voluntarily opted to remain in Cameroon face the challenge of integration into their new state. In March 2013, there was a new outflow of refugees from Bakassi into Nigeria following a spate of attacks and violence against the Nigerian population (Una 
2013). The attacks occurred at Efut Obot Ikot village and adjoining settlements on the Peninsula and were provoked by a misunderstanding over fishing rights and tax payments, leading to the death of five people with seventeen others missing and the displacement of a further 1,700 people (ibid.).

The primary research question addressed by this study centers around the relocation and resettlement of the affected Nigerians. Which factors influenced the choice of relocation and resettlement of the affected people? Four other sub-research questions are provided to further the understanding of the (re) settlement and integration of the affected people into their (new) communities. What are the implications of resettlement on the affected people of Bakassi? Are the people being effectively integrated into their new communities? How does the process promote the socio-economic welfare as well as the cultural dynamics of the affected people? Will the process of integration build peace and promote sustainable development?

\section{Theoretical Framework}

Relocation has been observed to lead to the loss of connections to ancestral and sacred sites, culture, history, and identity (Schama 1996). People who are displaced and thus have to relocate often experience loss of economic and social security (Shyamsundar and Kramer 1997). This is in line with Amos (2012) who highlights that displacement often leads to hunger and illness, both physical and mental. According to Crisp (2010), forced displacement obliges people to abandon their homes and seek refuge elsewhere, often at the price of serious threats to their welfare and rights. In a study conducted in Botswana, dominant social groups in the receiving communities overpowered relocated groups as the immigrant groups were regarded as competitors over scarce resources within the host communities (Bolaane 2004). In the process, they were treated as interlopers and denied access.

Resettlement of displaced persons involves processes and arrangements planned directly by the government or private developers to address their welfare and security challenges. This could be achieved by choosing an area to assist the displaced persons replace their housing, assets, livelihood, land, and access to resources and services in order to restore their socio-economic, cultural, and political conditions (de Sherbinin, Castro, and Gemenne 2010). Resettlement happens recurrently in real life and there is no uncertainty that it causes major economic losses and cultural disruption. The core rationale for resettlement is to avoid protracted refugee situations by seeking to achieve durable solutions to the conditions of the displacees. A durable solution is a situation where displaced persons no longer have any specific welfare and security needs that are linked to their displacement and can enjoy their human rights without discrimination on 
account of their displacement (UNHCR 2011).

The relocation and resettlement process is often controversial and imposed (from above) on the affected people. Isokon, Ekeh, and Icha (2014) assert that in most resettlement schemes, especially in Africa, the settlers were excluded from functional participation in the system, which made them feel a deep sense of neglect, abandonment, or alienation. Government and other related agencies involved in resettlement rarely consult with the affected people in the process of resettlement (Bartolome et al. 2000; Chatty and Colchester 2003). Karanth (2003) argues that these agencies often lack the expertise and experience required to facilitate such massive and sensitive projects, leading to poor planning and faulty execution. Furthermore, governments and relevant agencies vested with these responsibilities usually fail to assess and project the long-term impacts of relocation and resettlement on the affected people, who are effectively abandoned to cater for themselves (McLean and Straede 2003; Rangarajan and Shahabuddin 2006; Hilson, Yakovleva, and Banchirigah 2007).

Bartolome et al. (2000) observe that, in some cases, relocation and resettlement have recorded some measure of success as in the Kainji Dam resettlement in Nigeria in the late 1960s. In many other cases, owing to poor conception and execution, relocation and resettlement have rarely succeeded as the affected people are known to have retraced their steps back to the point where they were originally before the relocation.

Cernea (1999) argues that relocation and resettlement engender "landlessness, homelessness, marginalization, food insecurity, education loss, increased morbidity and mortality, loss of access to common property and social disarticulation." This reflects the findings of Onwe and Nwogbaga (2015) who report that displaced persons are exposed to a series of welfare and security challenges such as loss of land, loss of employment, loss of shelter, marginalization, increased morbidity and mortality, greater food insecurity, loss of access to common property/services, and social disarticulation. Added to this frightening reality is the inability of governments and related agencies to effectively provide the necessary succor and safety-nets for the affected people.

Angelovski (2015) evaluates the economic impacts, status, and needs of conflict affected population in the Donbass region of Ukraine. He observes that economic and social vulnerabilities of displaced persons are driven by deprivations in resources (financial, physical, human, and social). He stresses the need to support the productive capacities and help the affected people to meet their immediate needs and add to their income generation capacity. Hines and Balletto (2002) assess the needs of internally displaced persons in Columbia and are of the opinion that the displaced lose their social, legal, and economic ties and thus suffer considerable physical and psychological hardship. They further show how the World Food Programme (WFP) tried to understand and meet the food livelihood and security vulnerabilities of the displaced during different stages of 
displacement in Columbia. The Internal Displacement Monitoring Centre (2018) discusses the economic impacts of internal displacement across dimensions, time, countries, and displacement contexts and reveals that protracted displacement increases the vulnerability and exposure of already marginal populations and overstretches governments' capacities to respond. It is in this line that Das et al. (2016) affirms that the ultimate attainment of socio-economic stability for internally displaced persons (IDPs) takes years and may involve more than one generation. In spite of government policy and the provision of government funds for resettlement, IDPs may continue to suffer distress for many years after displacement (Ibanez and Moya 2006).

It is within this context that this study is framed; that is, to examine the (re) settlement program of the Bakassi returnees. Drawing on the effectiveness of the (re)settlement program, the study also aims to examine the implications for sustainable peace and development in the eastern Delta of Nigeria where the resettlement site is located.

\section{Methodology}

Data for this study was collected using survey research techniques in a study that was essentially exploratory targeting the experiences of persons affected by the resettlement after the Greentree Agreement. Fieldwork was conducted in New Bakassi in January 2013. The period of the research in Cameroon was influenced by weather conditions at the research sites (offshore) taking specifically into consideration the periods of low tides that enable easy and safe navigation across the channel into the Bakassi Peninsula. The study sites in Nigeria were the New Bakassi Local Government Area which is carved out of the Akpabuyo Local Government Area, resettlement camps in Ikang, Ekpiri Ikang, and Akpabuyo, and the Cross River State capital Calabar. Those for Cameroon were Idabato I, Idabato II, and Akwa. The researcher had to move forward and backwards between sites during field work. The Peninsula (in Cameroon) is accessible only by motor-boat from Oron in Nigeria as well as from Limbe in Cameroon. Akpabuyo is a few kilometers away from Calabar, the capital of Cross River State and is accessible by land transportation.

Participants were selected using a combination of non-probability sampling methods. Informants were either purposively selected (as key informants) or selected by the accidental and snowball techniques (for other local inhabitants). The latter consisted of an accumulation of referrals as each informant identified and suggested other informants relevant to the study. These techniques make for evident bias in the results because it was likely that we left out some informants. However, this was necessitated by the fact that respondents were difficult to locate especially in a context where the resettlement was still unstable. Besides, 
Table 1. Demographic Characteristics

\begin{tabular}{l|l|c|c}
\hline \multicolumn{1}{c|}{ Variable } & \multicolumn{1}{c|}{ Options } & $\mathrm{F}$ & $\%$ \\
\hline \multirow{4}{*}{ Age } & $25-34$ & 66 & 32.7 \\
\cline { 2 - 4 } & $35-54$ & 106 & 52.5 \\
\cline { 2 - 4 } & $55-65$ & 24 & 11.9 \\
\cline { 2 - 4 } & 65 and Above & 6 & 3.0 \\
\hline \multirow{4}{*}{ Marital Status } & Married & 168 & 83.6 \\
\cline { 2 - 4 } & Divorced & 5 & 2.5 \\
\cline { 2 - 4 } & Single & 20 & 10.0 \\
\cline { 2 - 4 } Education & Widowed & 104 & 4.0 \\
\cline { 2 - 4 } & First cycle secondary and below & 19 & 10.1 \\
\cline { 2 - 4 } & Sixth form & 7 & 3.7 \\
\cline { 2 - 4 } & University degree & 1 & 0.5 \\
\cline { 2 - 4 } & Postgraduate degree & & 55.0 \\
\hline
\end{tabular}

Source: Author's Field Research

given that the study was undertaken just a year after the effective implementation of the agreement, the study is essentially an exploratory one. The results are thus indicative of trends and cannot be generalized. The verbal consent of respondents was elicited and they were assured of confidentiality with which the information provided would be treated. Of a total of 250 questionnaires that were administered, 189 were returned completed (169 Nigerians and twenty Cameroonians). Twenty-eight were returned uncompleted and thus rejected. The rest (twenty-three) were not returned at all. It is worthy to note that we will be dealing with the sample of Nigerians alone because they were principally concerned with resettlement which is the object of this article. Interviews were conducted with twelve key informants (leaders of civil society organizations, traditional rulers, government functionaries, and politicians) selected on the basis of their role in the relocation and (re)settlement of the affected people. Table 1 shows the distribution of the participants' age, marital status, level of education, and nationality. The bulk of participants were between thirty-five and fifty-four years old while persons aged sixty-five years old and above were the fewest. The number of respondents within the age range of twenty-five and thirty-four years old was higher than those who were between fifty-five and sixty-five years old. Regarding marital status, a large majority were married with divorcees being the fewest. There were more single or never married respondents than widowed.

Table 1 shows that majority of the respondents attended first cycle secondary or less. This was followed by persons who had reached sixth form and holders of 
first degrees. There was only one person with a postgraduate degree in the sample. The results suggest that a majority of the respondents who reside in Bakassi (new and old) have low levels of education.

The researcher used local research assistants in the collection of the data. As most of the respondents, given their level of education, did not speak English, the research assistants translated and interpreted the instruments to non-English speaking respondents, and recorded their responses in English as well as taperecorded the interviews which were later transcribed into English. The research assistants were carefully selected from among a pool of civil society actors based on their knowledge of the local language and terrain as well as their familiarity with the issues under consideration having been involved in a number of commissioned studies on related issues. They were further trained based on the specific focus of the research and on the methods of administering of the research instruments. The translators' previous experience in the area and on the subject enabled a certain degree of confidence in their ability to effectively capture the views of the respondents without bias or any significant loss of information.

The questionnaire was divided into two sections. The first section elicited demographic characteristics of respondents directly related to the issue under investigation through close-ended questions as well as open-ended questions that generated information regarding respondents' view of the transfer of territory, their choice of relocation or settlement, as well as their view of their integration into their respective communities. The second elicited specific information regarding social disarticulation and access to developmental opportunities in their respective locations. Descriptive (frequencies), bar charts, as well as tests of association statistics (Pearson Product Moment Correlation and Multiple Regression Analysis) were used to describe and interpret the quantitative information collected. Personal observations also played an important part in the conduct of the research. The researcher experienced firsthand the challenges of the affected people. These observations form a critical part of the qualitative aspect of this study.

The main challenges of the fieldwork include "over-surveying" of the population. Being an issue of international importance, the (re)settlement of the Bakassi people has drawn significant international attention. As such, participants were rather weary and disillusioned from previous studies that did not really have a direct positive effect on their lives. Thus, they showed uncooperative and hostile attitudes toward the researcher. It was not until they were persuaded that the present study was not commissioned to provide solutions to their problems but an academic exercise aimed at identifying and analyzing the process of resettlement and integration that some respondents agreed to participate. The issue of compensation was another major hurdle for the study. This was an extremely difficult hurdle to overcome as many respondents would not cooperate without assurance of some form of compensation, which was given at the end 
of the study. Another critical challenge for the conduct of the research was uncooperative government officials who demanded to vet the survey material before administration. This challenge was overcome in Nigeria by simply bypassing the official and going directly to the resettlement camps. This was a particularly tricky strategy as the movement of the officials had to be monitored to avoid a confrontation and likely untoward consequences.

\section{Results}

\section{Satisfaction with Resettlement}

The results presented in Figure 1 reflect Nigerian returnees' level of satisfaction with the transfer of territory and their opinions regarding access to basic social benefits. The results indicate that a majority of Nigerians are unsatisfied with the decision to transfer Bakassi to Cameroon while others said they did not have access to social and basic development amenities. In interactive discussions with the relocated and "resettled" groups, they revealed that the displaced Bakassi indigenes were camped in dilapidated and overcrowded classrooms in Akwa Ikot Eyo Edem village, Akpabuyo Local Government Area of Cross River State. Further, they recounted that food security is a major challenge, health centers are without drugs, and there are no educational and economic opportunities. In spite of what many would describe as a kind gesture from the government, the "resettled" returnees described themselves as "political orphans." One Prince Aston Joseph said, "I hate to hear that we have been resettled. They provided over 2,800 households with 343 mini-flats and they call that resettlement?" (Ukwayi and Anam 2017). Others enjoined to attest that Bakassi people are fishermen and marry more than one wife and give birth to a large number of children. They allocated us empty houses with no facilities. The only property given to each household is a single bed (ibid.). Others exclaimed:

Figure 1. Satisfaction of Nigerian Returnees with Resettlement in New Bakassi

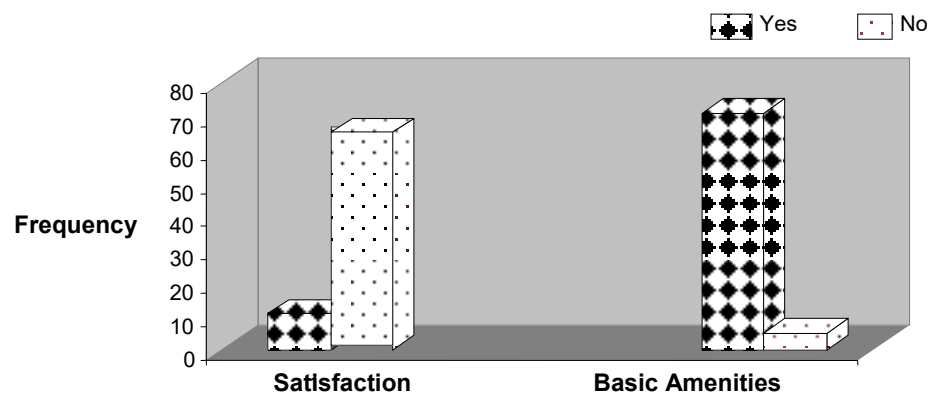

Source: Author's Field Research 
Can you imagine how a family with between eight to fifteen children will share a bed?... When we moved here in 2010 , they only fed us for three months, and after that then they abandoned us. No food, no rehabilitation, no resettlement. Their talk of empowerment is untrue. They only brought forms for skill acquisition and we filled and returned to them but we haven't heard from them ever since. None of the skill acquisition programmes has been implemented here (ibid.).

\section{Effective Integration}

Table 2 presents the results of the descriptive statistics regarding people's views on whether they are being well integrated into their communities or not. The results reveal that the majority of Nigerians felt that they were not satisfied with the arrangements following the Greentree Agreement. A large proportion did not enjoy government-led advocacy to facilitate their integration into their new settlements. The results thus suggest that adequate provisions were not made by the government of Nigeria to ensure that people were resettled and fully integrated into their local communities.

\section{(Re)settlement and Socio-Economic/Cultural Dynamics}

Table 3 presents the distribution of occupations of Nigerian residents in New Bakassi. A majority of the residents of New Bakassi in Nigeria engage in fishing and farming more so than other occupations. This made it impossible for them to find the same opportunities in their new environments which were both

Table 2. Effective Integration into Communities

\begin{tabular}{c|c|c|c|c|c|c}
\hline \hline \multirow{2}{*}{} & \multicolumn{2}{|c|}{$\begin{array}{c}\text { Satisfaction with Living } \\
\text { Condition }\end{array}$} & \multicolumn{2}{|c|}{ Access to Basic Amenities } & \multicolumn{2}{c}{$\begin{array}{c}\text { Government Advocacy for } \\
\text { Integration }\end{array}$} \\
\cline { 2 - 7 } & Satisfied & Not Satisfied & Access & No Access & Advocacy & No Advocacy \\
\hline F & 11 & 65 & 71 & 5 & 28 & 48 \\
\hline$\%$ & 14.5 & 85.5 & 93.4 & 6.6 & 36.8 & 63.2 \\
\hline
\end{tabular}

Source: Author's Field Research

Table 3. Occupation of the Resettled Persons in Current Location

\begin{tabular}{l|c|c}
\hline \multicolumn{1}{c|}{ Occupation } & F & $\%$ \\
\hline Fishing/farming & 43 & 56.6 \\
\hline Business & 28 & 36.8 \\
\hline Civil Servant & 3 & 3.9 \\
\hline Others & 2 & 2.6 \\
\hline
\end{tabular}

Source: Author's Field Research 
Table 4. People in the Same Occupation after Resettlement

\begin{tabular}{l|c|c}
\hline \hline & F & $\%$ \\
\hline Same Occupation & 30 & 39.5 \\
\hline New Occupation & 46 & 60.5 \\
\hline
\end{tabular}

Source: Author's Field Research

land locked with no possibilities for either fishing or lucrative trade unlike in the Bakassi in Cameroon where its waters and transit plus the border area are fertile grounds for these activities. This explains why they were many dissatisfied displacees despite the amenities provided by the home government.

The results in Table 4 indicate that a larger proportion of persons resettled in New Bakassi claim to have changed careers or jobs after resettlement. The implication of the results is that the careers of many Nigerians who reside in New Bakassi are more affected by the resettlement process. Relocation meant loss of jobs which are not readily available in the new location. Ekpeyong Esong, who used to be a fisherman in Bakassi, reveals to Olukoya (2012) that, "life is very difficult for me...I no longer fish for there is no job here." As the majority are engaged in fishing/farming, access to water-bodies and arable farmland is important. However, owing to lack of access to these resources in the New Bakassi, many returnees have to look for other means of livelihood. Warfa et al. (2012) point out that such a situation creates financial hardship because they are unable to support themselves and their families on the income from menial jobs. Lee et al. (2015) agree that in order to provide for their families, they may work multiple menial jobs, and their absence from home limits the time that they are able to spend with their children. Many respondents told this researcher that they had to learn new trades to earn a living. Many others commute on foot between their new locations in New Bakassi and the ocean, a distance of about 10-12 miles in order to engage in fishing.

The results in Table 5 show that the trend of resettled Nigerians in New Bakassi is towards social disarticulation and deprivation occasioned by their relocation and resettlement. As shown elsewhere in this article, these people are unsatisfied with the half-hearted efforts of the Nigerian government regarding their resettlement in these locations. On all counts regarding social disarticulation, their response weighed heavily on the negative.

The results in Table 6 illustrate the outcome of the Pearson Product Moment Correlation analysis between Nigerians' decision to relocate out of or remain in Bakassi and the predictor variables. The results show a significant positive association between Nigerians' national identity and length of stay in Bakassi and the choice to remain in or relocate out of Bakassi after the Greentree Agreement. Additionally, the results also indicated that there was a significant positive relationship between Nigerians' national affiliation and the period of time they 
Table 5. Social Issues Affecting Resettled Returnees in New Bakassi

\begin{tabular}{c|l|c|c|c|c}
\hline \multicolumn{2}{l|}{} & \multicolumn{3}{|c}{ Frequency } \\
\hline No. & Item & - & $\%$ & + & $\%$ \\
\hline 1 & Access to Productive Resources and Common Property & 56 & 73.7 & 20 & 26.3 \\
\hline 2 & Access to Resources & 71 & 93.4 & 5 & 6.6 \\
\hline 3 & Access to Landless & 74 & 97.4 & 2 & 2.6 \\
\hline 4 & Housing & 64 & 84.2 & 12 & 15.8 \\
\hline 5 & Dignity and Honor & 67 & 88.2 & 9 & 11.8 \\
\hline 6 & Food Insecurity & 73 & 96.1 & 3 & 3.9 \\
\hline 7 & Morbidity and Mortality & 69 & 90.8 & 7 & 9.2 \\
\hline 8 & Social Disarticulation & 67 & 88.2 & 9 & 11.8 \\
\hline 9 & Marginalization and Deprivation & 69 & 90.8 & 7 & 9.2 \\
\hline 10 & Access to Education and other Development Opportunities & 73 & 96.1 & 3 & 3.9 \\
\hline
\end{tabular}

Note: “+" denotes being positively affected while “-" denotes being negatively affected Source: Author's Field Research

Table 6. Correlation Matrix for the Relationship between Predictor Variables and Nigerians' Decision to Relocate or Remain in Bakassi

\begin{tabular}{l|c|c|c|c}
\hline \hline & A & B & C & D \\
\hline A. Relocate from or remain in Bakassi & & .762 & & .773 \\
\hline B. Length of stay in Bakassi & .762 & & & .331 \\
\hline C. Access to social amenities & & & & \\
\hline D. Nationality & .773 & .331 & & \\
\hline
\end{tabular}

Note: $>0.5$ denotes significant positive correlation coefficients while $<0.5$ denotes positive negative correlation coefficients.

$\rho_{A B}=0.762$. Denotes a strong positive correlation between A and B

$\rho_{B D}=0.331$. Indicates a weak positive correlation between $\mathrm{B}$ and $\mathrm{D}$

$\rho_{A D}=0.773$. Signifies a strong positive correlation between A and D

The symbol $\rho_{X Y}$ signify the Pearson Product Moment Correlation Coefficient between X and Y.

Source: Author's Field Research

live in Bakassi. The results suggest that Nigerians born in Bakassi and those who have lived in Bakassi for a long period of time are not likely to remain on Bakassi Peninsula after the transfer of the territory to Cameroon. This group constitutes the bulk of the affected people who voluntarily chose relocation and resettlement in Nigeria. 
Table 7. Model Summary: Coefficient and T-value of Multiple Regression Analysis of the Predictor Variables and Outcome Variable for Nigerians

\begin{tabular}{l|c|c|c|c|c}
\hline \hline \multirow{2}{*}{\multicolumn{1}{c|}{ Model }} & \multicolumn{2}{|c|}{$\begin{array}{c}\text { Unstandardized } \\
\text { Coefficients }\end{array}$} & $\begin{array}{c}\text { Standardized } \\
\text { Coefficients }\end{array}$ & $\mathrm{t}$ & \multirow{2}{*}{ Sig. } \\
\cline { 2 - 5 } & \multicolumn{1}{c|}{$\mathrm{B}$} & Std. Error & Beta & & \\
\hline (Constant) & 5.892 & .305 & & 19.293 & .000 \\
\hline Nationality & 1.025 & .074 & .585 & 13.756 & .000 \\
\hline Access to social amenities & .011 & .212 & .002 & .053 & .958 \\
\hline Length of stay in Bakassi & .926 & .069 & .568 & 13.386 & .000 \\
\hline
\end{tabular}

Model Summary

Multiple R (Adjusted) $=.885$ Multiple R2 (Adjusted) $=.880$

Standard Error Estimate $=.456$

$\mathrm{F}=184.703$

Sig. $=.000$

Source: Author's Field Research

Table 7 shows the results of the multiple regression analysis of the factors which predict Nigerians' decision to relocate from or remain in Bakassi after the Greentree Agreement. The results indicate that length of stay in Bakassi, access to social amenities, and nationality jointly contributed a coefficient of multiple regression of .885 and a multiple correlation square of .880 towards Nigerian's decision regarding whether or not to remain or relocate. The results suggest that $88 \%$ of the total variance of Nigerian's decision to relocate from or remain in Bakassi after the Greentree Agreement was accounted for by the combination of these explanatory variables. Moreover, the results further reveal that the analysis of variance of the multiple regression is significant $(\mathrm{F}=184.703, \mathrm{p}=.001)$. In addition, the results also showed that nationality was the most potent factor contributing to Nigerians' decision regarding whether to remain in or relocate out of Bakassi after the Greentree Agreement. Length of stay also influenced the decision of the people. Access to basic social amenities did not make any significant contribution to Nigerians' decision on whether to relocate or remain in Bakassi after the Greentree Agreement.

\section{Discussion}

The transfer of Bakassi Peninsula from Nigeria's control to Cameroon based on the Greentree Agreement has significant implications for the affected people of Bakassi irrespective of their choice to remain on the Peninsula or to relocate and resettle in other parts of Nigeria. As shown by the study, a majority of the inhabitants of Bakassi, prior to the Greentree Agreement, were Nigerians. The 
option presented to them was to remain and be integrated into Cameroon or relocate and be resettled in Nigeria. Following the Agreement, many of the Nigerians chose to relocate to Nigeria rather than remain and be integrated into Cameroon. Their choice was primarily influenced by their identification as Nigerians above other considerations. Indeed, some of the returnees who participated in the survey for this study claim that they lost their life investments and lots more by returning to Nigeria. They claim they would rather return to Nigeria than remain in Cameroon given the disposition of the Cameroonian gendarmes towards Nigerians on the Peninsula. Some of the victims testified that when they are out fishing, the gendarmes attack their women and children at home and have, in some cases, sent them out of their houses because they failed to pay taxes.

The population of the Peninsula remains significantly Nigerian, indicative of the fact that many inhabitants of the Peninsula of Nigerian origins opted to stay after the Greentree Agreement. This means that though Nigerian nationality was a major determinant of the decision of many people to leave Bakassi and be resettled in other parts of Nigeria, there were other intervening variables which influenced the choice of some other inhabitants to remain rather than relocate away from the Peninsula. Some of these variables include Cameroonian nationality, length of stay (by implication, level of disarticulation and disconnection from Nigeria) on the Peninsula, access to work, and the unalluring prospect and uncertainty of resettlement, amongst others.

National affiliation correlates with the degree of satisfaction with the transfer of territory. A majority of Cameroonian inhabitants of the Peninsula were happy with the transfer of the Peninsula to Cameroon, while the majority of Nigerians (returnees) were unhappy with the transfer. This is quite understandable as the transfer compelled many Nigerians to relocate from their ancestral homes where they had always lived and had significant social and economic investments. Relocating meant an uprooting, a displacement, and destabilization of their settled lifestyle. It is gambling the certainty and stability of the familiar for the uncertainty of the unknown, which their resettlement in other parts of Nigeria meant. On the other hand, for the Cameroonians, Bakassi is Cameroon and home to them. There was no relocation to other parts of Nigeria for them. Indeed, for the Cameroonian, it was good that the Nigerians returned home as they would then have less competition for resources. For the Nigerians who chose to remain, their choice was influenced by their unwillingness to trade the known for the unknown. They have investments, either in the social life or in the booming fishing trade of the Peninsula. In any case, they lose nothing by remaining on the Peninsula as per the Greentree Agreement, they are still Nigerians, but residents of Cameroon.

Relocation also has implications for the living conditions of the affected people. While the people who remain in Bakassi did not suffer the effects of 
disruption and the need for shelter, those who relocated to Nigeria have had to contend with living in camps and with limited access to basic amenities. Moreover, they also have to contend with loss of jobs and a not-so-receptive host community. They are further denied full access to the political space in their new local government as they have to share patronage with the host community, who are neither displaced nor affected by relocation. Government-led advocacy to ameliorate the impact of relocation and resettlement has not been effective due to what has been termed government insensitivity and corruption. For example, each affected family (irrespective of size) upon relocation to Nigeria, was paid a NGN\$ 5000 (or US\$33) monthly stipend by the government. This meager sum was unilaterally stopped without notice and explanation by the government and has not been provided since February of 2012. Houses earmarked for resettlement were either allocated to non-affected people or forcefully taken over by members of the host community (interview with returnees at Ekpiri Ikang, January 2013).

The affected people of New Bakassi have become despondent due to their perceived abandonment by the Nigerian state. They have chosen the path of peaceful protest to register their dissatisfaction with the government's treatment of their matter. Led by the Bakassi Peoples Assembly, the affected people have succeeded in getting the Federal Government to set up a committee, headed by the Vice-President, to address the issues of concern to the people. The major contention of the affected people is what they call "proper resettlement" on Dayspring Island, where they would have access to the sea for fishing, be able to properly organize themselves politically, and be free of the problems posed by their current host community. The committee's report, submitted in June 2013, is awaiting implementation by the Federal Government. The incessant insensitivity of the Nigerian government to the plight of the Bakassi returnees has made the people more frustrated and infuriated. This situation is further exacerbated by the indigenous-incomer divide that intensifies the marginalization of the angry returnees. Youngsters in displaced camps are vulnerable insurgent groups. This neglect could lead to insurgency and criminality given the militant activities causing tension already at Dayspring I and II under the aegis of Bakassi Freedom Fighters (BFF).

\section{Conclusion}

The arena of public policy in Africa tends to be characterized largely by a disconnection between policies and implementation. As noted above, this is due to the tendency to overlook the critical historical, cultural, and social context of society, which makes implementation an arduous task. In addition, relocation and resettlement is usually imposed (from above), without the inputs of the affected people. The consequence is that the goals of relocation and resettlement become 
hard to accomplish.

This has played out in the resettlement of the affected people of Bakassi in Nigeria. It appears as though the Nigerian state was ill-prepared for the resettlement as the people have been largely left to their own devises with insignificant government intervention to make their integration into their new communities smooth and effective. This has pitched the incomers against the host community in Akpabuyo, with the affected people claiming marginalization, redirection of relief materials, and denial of access to the political space and government patronage. The lives of the affected people have been disrupted with little or no intervention to effectively resettle them. The majority have changed occupations as they can no longer engage in fishing; some have been trained in new skills, but without access to capital they could not invest their skills in productive ventures. Tension and mutual distrust have thus grown between the affected people and the host community. Had the affected people reacted based on their level of discontent, conflict would have flared in New Bakassi.

On the Bakassi Peninsula, the fortunes of the people are slightly different. Though access to social amenities is limited, the people do not have to contend with the disarticulation and disruption associated with relocation characterized by the loss of shelter, jobs, etc., and having to endure the ignominy of camp accommodation and relying on handouts to meet the basic needs of their families. While the Nigerian returnees have limited access to the political space, their Cameroonian counterparts, especially Nigerian residents, suffer disenfranchisement as they are deprived civic rights as well as access to other resources of state.

Greater government involvement is required in both countries to ease the issues associated with both relocation and resettlement as well as of integration into new communities or integration as new members. Effective governmentled advocacy is required to educate the affected people of their civic rights and responsibilities as well as an initiative to engender the socio-economic and political integration of new members into the community. The reduction of the impacts of the trauma associated with the loss of livelihood, homes, and settlement would promote the rate of integration. Similarly, inclusion initiatives to promote the integration of new members would aid their acceptance as well as their sense of belonging.

Furthermore, to defuse tensions that have built up between the two countries, it is important to promote the virtues espoused in the Greentree Agreement. Owing to recent developments that led to a new outflow of people of Nigerian descent from Bakassi Peninsula to Nigeria due to conflict between them and Cameroonian gendarmes, Bakassi may not be a settled issue yet. Rather than stoke the embers of interstate conflict, Bakassi should be considered a testament to peaceful resolution of boundary conflict between two African states. The Mixed Commission should be retained as an ad hoc commission to deal with 
unresolved issues along this boundary.

\section{Acknowledgements}

This study was made possible by support from the Social Sciences Research Council's African Peacebuilding Network research grant with funds provided by Carnegie Corporation of New York.

\section{References}

Amos, Valerie. 2012. “Preventing Displacement.” Forced Migration Review 41 (4): 4.

Angelovski, Dragan. 2015. "Socio-Economic Impact and Needs Assessment: Donbass, Ukraine." Food and Agriculture Organization of the United Nations. http://www.fao. org/3/a-i5171e.pdf (accessed March 21, 2019).

Bartolome, Leopoldo Jose, Chris de Wet, Harsh Mander, and Vijay Kumar Nagraj. 2000. "Displacement, Resettlement, Rehabilitation, Reparation and Development." Paper Prepared for the World Commission on Dams. http://siteresources.worldbank.org/ INTINVRES/Resources/DisplaceResettleRehabilitationReparationDevFinal13main. pdf (accessed March 21, 2019).

Bolaane, Martseo. 2004. "The Impact of Game Reserve Policy on the River BaSarwa Bushmen of Botswana." Social Policy and Administration 38 (4): 399-417.

Calabar, Emma Una. 2013. "Nigeria: Deaths in Bakassi-Nigerians in Ceded Territory Accuse Cameroun of Breaching Pact.” Vanguard, April 7. http://www.vanguardnge. com/2013/04/deaths-in-bakassi-nigerians=in-ceded-territory=accuse-cameroonof=breaching-pact/ (accessed June 17, 2018).

Chatty, Dawn, and Marcus Colchester. 2003. "Introduction: Conservation and Mobile Indigenous Peoples.” In Conservation and Mobile Indigenous Peoples, Displacement, Forced Settlement and Sustainable Development, eds. Dawn Chatty and Marcus Colchester. New York: Bergnan Books.

Crisp, Jeff. 2010. "Forced Displacement in Africa: Dimensions, Difficulties, and Policy Directions." Refugee Survey Quarterly 29 (3): 1-27.

Das, Tuhin K., Sushil K, Haldar, Ivy Das Gupta, and Sudakhina Mitra. 2016. "Conflict, Displacement, and Inequality of Opportunity." Asian Journal of Peacebuilding 4 (2): 137-159.

de Sherbinin, Alex, Marcia Castro, and Francois Gemenne. 2010. “Preparing for Population Displacement and Resettlement Associated with Large Climate change Adaptation and Migration Projects." Background Paper for the Bellagio Workshop, November $2-6$.

Dos Santos, Gustavo Placido. 2014. “The Bakassi Peninsula: A Discreet Problem with Major Implications.” Portuguese Institute of International Relations and Security (IPRIS) Viewpoints, October. https://www.academia.edu/8665851/The_Bakassi_ Peninsula_A_Discreet_Problem_with_Major_Implications (accessed March 21, 2019). 
Ekolok, Sixtus K. n.d. "Conflict Over the Bakassi Peninsula: A Natural Resource Conflict?” M.A. Thesis, Göteborg University.

Hilson, Gavin, Natalla Yakovleva, and Sadia Mohammed Banchirigah. 2007. “'To Move or Not To Move': Reflections on the Resettlement of Artisanal Miners in the Western Region of Ghana." African Affairs 106 (424): 413-436.

Hines, Deborah, and Raoul Balletto. 2002. "Assessment of needs of Displaced Persons in Colombia." Overseas Development Institute, Working Paper 189, December. https:// www.odi.org/sites/odi.org.uk/files/odi-assets/publications-opinion-files/2676.pdf (accessed March 21, 2019).

Ibanez, Ana Maria, and Andres Moya. 2006. “The Impact of Intra-State Conflict on Economic Welfare and Consumption Smoothing: Empirical Evidence for the Displaced Population in Columbia." HiCN Working Paper 23. https://papers.ssrn. com/sol3/papers.cfm?abstract_id=1392415 (accessed September 25, 2018).

ICJ (International Court of Justice). 2002. "Press Release 2002/26: 'Land Maritime Boundary between Cameroon and Nigeria (Cameroon v. Nigeria Equatorial Guinea Intervening)."” October 10. https://www.icj-cij.org/files/case-related/94/09420021010-PRE-01-00-EN.pdf (accessed March 20, 2019).

Internal Displacement Monitoring Centre. 2018. "Assessing the Economic Impacts of Internal Displacement: Conceptual Framework.” June. http://www.internaldisplacement.org/sites/default/files/inline-files/20180608-idmc-economic-impactsframework.pdf (accessed March 21, 2019).

Iriekpen, Davidson, and Onwuka Nzeshi. 2012. "FG Rules Out Review of ICJ Judgment on Bakassi." This Day, August 27. http://www.thisdaylive.com/articles/fg-rules-outreview-of-icj-judgment-on-bakassi/123309/ (accessed March 21, 2019).

Isokon, B. E., J. E. Ekeh, and C. I. Icha. 2014. "Fishing as a Source of Livelihood and Sustainable Growth in a Resettlement Scheme: The Case of Bakassi Resettlement Programme in Cross River State, Nigeria." Journal of Environmental Issues and Agriculture in Developing Countries 6 (1): 22-29.

Karanth, Krithi K. 2003. "Forest Use and Human-wildlife Conflicts in Bhadra Wildlife Sanctuary, India." Tropical Resources Bulletin 22: 48-58.

Konings, Piet. 2005. "The Anglophone Cameroonian-Nigeria Boundary: Opportunities and Conflicts." African Affairs 104 (415): 275-301.

Lee, Sungkyu, Sunha Choi, Laurel Proulx, and Jennifer Cornwell. 2015. "Community Integration of Burmese Refugees in the United States." Asian American Journal of Psychology 6 (4): 333-341.

McLean, Joanne, and Steffen Straede. 2003. "Conservation, Relocation and Paradigms of Park and People Management - a Case Study of Padampur Villages and Royal Chitwan National Park, Nepal." Society and Natural Resources 16: 509-526.

Olukoya, Sam. 2012. "Bakassi People Bitter Over Loss of Homeland in Nigeria." Voice of America News, October 20. https://www.voanews.com/a/bakassi-people-bitter-overloss-of-homeland-in-nigeria/1530408.html (accessed March 21, 2019).

Onwe, Sunday O., and David M.E. Nwogbaga. 2015. "Reflections on the Challenges of Displacement and Effective Resettlement Strategies." Journal of Humanities and Social Science 20 (3): 51-56.

Price, Felicia. 2005. "The Bakassi Peninsula: The Border Dispute between Nigeria and Cameroon." Inventory of Conflict and Environment (ICE), Case Studies Number 163, 
November.

Rangarajan, Mahesh, and Ghazala Shahabuddin. 2006. "Displacement and Relocation from Protected Areas: Towards a Biological and Historical Synthesis." Conservation and Society 4 (3): 359-378.

Schama, Simon. 1996. Landscape and Memory. London: Fontana Press.

Shyamsundar, Priya, and Randall A. Kramer. 1997. "Biodiversity Conservation - At What

Cost? A Study of Households in the Vicinity of Madagascar's Mantadia National Park." AMBIO A Journal of the Human Environment 26 (3): 180-184.

Ukwayi, Joseph K., and Bassey Anam. 2017. "Internally Displaced Persons and Emerging Security Challenges: an Assessment of the Bakassi Refugee Camp in Cross River State, Nigeria." International Journal of Development Strategies in Humanities, Management and Social Sciences 7 (2): 125-134.

Una, Emma. 2013. "Deaths in Bakassi: Nigerians in Ceded Territory Accuse Cameroun of Breaching Pact." Vanguard, April 7.

UNHCR (United Nations High Commissioner for Refugees). 2011. Protecting the Human Rights of Internally Displaced Persons in Natural Disasters: Challenges in the Pacific. http://pacific.ohchr.org/docs/IDP_report.pdf (accessed March 21, 2019).

Warfa, N., S. Curtis, C. Watters, K. Carswell, D. Ingleby, and K. Bhui. 2012. "Migration Experiences, Employment Status and Psychological Distress among Somali Immigrants: A Mixed-Method International Study." BMC Public Health 12: 749-760.

\footnotetext{
Aloysius Ngalim was trained as a historian and obtained a Ph.D. at the University of Nigeria, Nsukka. Currently, he is an Associate Professor in the Department of History at the University of Buea, Cameroon. A Fulbright Scholar and member of scholarly groupings such as CODESRIA and the African Peacebuilding Network of the Social Science Research Council. He also does consultation work with United Nations Economic Commission for Africa on transboundary natural resources disputes in Africa. His research interests focus broadly on issues of agricultural and development history, natural resources, conflict and mediation in the third world. He has published scholarly papers in peer-reviewed national and international journals.
}

Submitted: April 6, 2018; Revised: October 7, 2018; Accepted: November 26, 2018 
